\title{
Fatigue index and anaerobic power obtained in different surfaces types
}

\section{Índice de fadiga e potência anaeróbia obtida em diferentes tipos de solo}

\author{
Walmir Romário dos Santos ${ }^{1}$ \\ (D) https://orcid.org/0000-0001-5558-3109 \\ Clodoaldo José Dechechi² \\ (D) https://orcid.org/0000-0002-5151-5130 \\ Isac Alexandre Ferreira da Silva ${ }^{1}$ \\ (D) https://orcid.org/0000-0001-5222-1444 \\ Matheus Machado Gomes ${ }^{1}$ \\ (D) https://orcid.org/0000-0002-2123-5699 \\ Gustavo Augusto Fernandes Correia \\ (1) https://orcid.org/0000-0002-7914-6840 \\ Pedro Pinheiro Paes ${ }^{3}$ \\ (1) https://orcid.org/0000-0002-6765-5672 \\ Wlaldemir Roberto dos Santos ${ }^{4}$ \\ (D) https://orcid.org/0000-0001-5706-2243
}

Abstract - Due to the high intensity of competitive sports, the anaerobic power is a very important physical capacity for most sports. However, the diverse surfaces were these sports may interfere in the performance of this capacity. In running-based sports, the Running Anaerobic Sprint Test-RAST is largely used to evaluate anaerobic power. Considering the specificity of each sport, it is suggested to apply this test on the surface that it is played. Thus, the aim of the present study is to analyze the performance of RAST on different surfaces. The sample was composed by 10 subjects, mean age $20.2 \pm 0.9$ years old, mean height $1.8 \pm 0.1$ meters, mean body weight $77.4 \pm 15.9 \mathrm{~kg}$, and practice time of $6.0 \pm 2.0$ years. RAST was conducted on three different surfaces (hard, grass and sand). The maximum and minimum power and the fatigue index were compared between the surfaces. The results indicate that maximum and minimum power were lower in sand when compared to grass and hard surfaces. However, the fatigue index did not change. So, we observed that the surface is an important factor in RAST performance.

Key words: Anaerobic threshold; Athletic performance; Exercise; Physical fitness; Running.

Resumo -Devido à alta intensidade do esporte competitivo, a potência anaeróbia é uma capacidade física de natureza decisiva para a maioria das modalidades esportivas. Entretanto, diferentes tipos de superfícies onde são jogadas estas modalidades podem interferir no desempenho dessa capacidade física. Em esportes cuja corrida é base para sua prática, o Running Anaerobic Sprint Test - RASTé largamente utilizado para a avaliação da potência anaeróbia e levando em consideração à especificidade de cada esporte, sugere-se que este teste seja aplicado na superfície onde ele é praticado. Neste sentido, o objetivo do presente estudo foi analisar o desempenho no RAST em diferentes tipos de solo. A amostra foi composta por 10 sujeitos com idade média de 20,2 $\pm 0,9$ anos, estatura média de 1,8 \pm 0,1 metros, massa corporal média de 77,4 $\pm 15,9 \mathrm{~kg}$ e histórico médio de treinamento de 6,0 $\pm 2,0$ anos. O RAST foi realizado em três superfícies diferentes (cimento, grama e areia). A potência máxima e minima e o indice de fadiga foram comparados entre os solos. Os resultados indicam que as potências máxima e minima foram menores na areia comparadas a grama e ao cimento. No entanto, não houve diferença no indice de fadiga. Conclui-se que o tipo de solo é um fator que influencia no desempen ho do RAST.

Palavras-chave: Aptidão física; Corrida; Desempenho atlético; Exercício; Limiar anaeróbio.
1 Universidade de São Paulo. Escola de Educação Física e Esporte de Ribeirão Preto. Ribeirão Preto, SP. Brasil.

2 Universidade de São Paulo. Faculdade de Medicina de Ribeirão Preto. Ribeirão Preto, SP. Brasil.

3 Universidade Federal de Pernambuco. Departamento de Educação Física. Recife, PE. Brasil.

4 Universidade Federal de Pernambuco. Centro de Biociências. Recife, PE. Brasil.

Received: 22 April 2019 Accepted: 07 January 2020

How to cite this article Santos WR, Dechechi CJ, Silva IAF, Gomes MM, Correia GAF, Paes PP, Santos WR. Fatigue index and anaerobic power obtained in different surfaces types. Rev Bras Cineantropom Desempenho Hum 2020, 22:e66206. D0I: http://dx.doi. org/10.1590/1980-0037.2020v22e66206

Copyright: This work is licensed under a Creative Commons Attribution 4.0 International License. 


\section{INTRODUCTION}

The need for performance improvement in sports has driven sports science to develop ways to improve athletes' performance ${ }^{1}$. Physical capacity is the main component of sports performance, using aerobic or anaerobic systems on practice. However, the anaerobic system has proven to be extremely important in several disciplines, mainly on those that are intermintent ${ }^{2}$. The importance of anaerobic system on mainly aerobic disciplines is due to the intensity overcome the volume in many situations on collective sports ${ }^{3}$. Thus, intermittent activities are directly linked to muscular glycogen stores ${ }^{4}$ and to ATP ressynthesis from phospocreatine ${ }^{5}$.

So, techniques to evaluate anaerobic power are extremely important to monitor the efficiency ${ }^{3}$. Tests like Wingate ${ }^{6}$, that uses short distances like 10 or 20 meters sprints and RAST - Running Anaerobic Sprint Test ${ }^{7}$ are used to evaluate anaerobic power in sports. Due to its characteristics, RAST is widely used in disciplines where technical expertise is needed when using intermittent running on its practice ${ }^{8-10}$, confirming the specificity principle ${ }^{11}$. Besides that, RAST results allow obtaining the fatigue index from the athlete to monitor physical conditioning ${ }^{12}$.

Although several studies have shown the influence of different types of soil on physical exercise intensity, helping on the training prescription to court sports played on hard floors (basketball, volleyball, futsal, and handball), on grass (soccer) and sand (beach soccer, beach volley, and beach hand) $)^{9,13-16}$, few studies addressed the influence of the type of soil on performance and fatigue index on RAST. It is an efficient method to evaluate anaerobic power on athletes and physically active individuals, allowing better conditions to physical and sports training programs. The aim of this study was, then, evaluate anaerobic power and fatigue level on RAST in different types of soil (cement, sand, and grass).

\section{METHODS}

\section{Subjects and Experimental Design}

The sample was composed by ten individuals, all college students, all physically active males. The subjects did not participate in a specific sports discipline described in Table 1. The participation was voluntary, being informed about all risks and benefits. The inclusion criteria were signing the free consent form, medical approval for exercise practice, and to be engaged on any regular physical exercise program for at least three months. All procedures underwent all ethical norms accord to resolution 466/2012, regulating human research (UNICEP, CAAE: 58888516.4.0000.5380 and protocol number: 1705382). After participant selection, they were submitted to anthropometric data colletion, anamnesis and oriented to RAST execcution. The test was conducted on all three types of surfaces, within a 72-hour interval between them, following this specific order: cement, grass, and sand. 


\section{Anthropometric measures and sample characterization}

The height and weight were measured using an electronic scale with a stadiometer (Welmy ${ }^{\oplus}$, Santa Bárbara d'Oeste, São Paulo, Brasil, accuracy of $0.1 \mathrm{~cm}$, and $0.1 \mathrm{~kg}$ ). Age and training history were collected in the previous anamnesis prior to the test.

\section{Running anaerobic sprint test - RAST}

Following the protocol suggested by Zagatto, Beck, and Gobato ${ }^{17}$, RAST is composed by 6 sprints of 35 meters, performed at maximum speed, and 10 second intervals between each sprint. To delimitate the 35 meters, a scale was used, and the distance was marked by cones. Three researchers participated in the data collection, two of them at the end cone to register sprint time. After the collection, the mean time from the researchers was calculated and considered to decrease the error between researchers. The recovery time was registered by a third researcher. Professional chronometers were used for time collection (Guepardo Of0100, Guarulhos, São Paulo, Brasil).

\section{Test guidelines}

RAST protocol was conducted in four phases: (1) 10-minute warmup with light to moderate running on the surface where the test was conducted (cement, grass, and sand); (2) pause to recovery for three minutes; (3) sixsprints test; (4) active recovery with 2-minute walking. This protocol in this study was adapted from Keir, Thériault, and Serresse ${ }^{18}$. The first test was conducted on cement, followed by grass and sand, with 72-hours intervals between tests, always applied at $7 \mathrm{pm}$.

The subjects were tested on the facilities of the University of São Paulo, campus de Ribeirão Preto. On cement (closed space, gymnasium) and grass (open space, soccer field), shoes for physical activities were used while on sand (open space, sand court), the subjects were tested barefoot. The weather conditions were very similar in all tests, with no rain occurring in any test.

\section{Maximum and minimum strength and fatigue index}

After RAST on all surface, it was verified the Fatigue Index (FI) for each subject on each surface. To obtain the FI, the maximum (MAXS) and minimum (MINS) strength and time (T) were used through the equation $\mathrm{FI} \%=\mathrm{MAXS} \times \mathrm{MINS}) / \mathrm{MAXS}^{12}$. To obtain the strength to each sprint, the body mass $(\mathrm{BM})$, distance $(\mathrm{D})$, and time $(\mathrm{T})$ were used through the equation $\mathrm{S}=\mathrm{BM} \times \mathrm{D}^{2} / \mathrm{T}^{3}$.

\section{Statistical Analysis}

The Statistical Package for the Social Sciences (SPSS), version 17.0 was used. The data are described in mean and standard deviation. To the data normality analysis, the Shapiro-Wilk test was used, and the Mauchly test was used to evaluate its sphericity. Since the data are note spheric, the 
Greenhouse-Geisser correction factor was used. To analyze the mean differences, repeated measures ANOVA were used, with Tukey post hoc. The significance level was set at $5 \%$.

\section{RESULTS}

The sample characterization is in table 1.

Table 1. Anthropometric characteristics, age, and training history of the subjects.

\begin{tabular}{lc}
\hline Variable & Mean \pm Standard Deviation \\
\hline Age (years old) & $20.2 \pm 0.9$ \\
Height $(\mathrm{cm})$ & $178.0 \pm 0.1$ \\
\hline Total body mass $(\mathrm{kg})$ & $77.4 \pm 15.9$ \\
Training history (years old) & $6.0 \pm 2.0$ \\
\hline
\end{tabular}

Table 2 presents the performance variables obtained on all surfaces. There were differences between surfaces for minimum and maximum strength $(\mathrm{p}<0.001)$. Post hoc tests revealed that maximum and minimum strength were lower on the sand when compared to cement and grass, with no difference between cement and grass. Regarding Fatigue Index, there was no difference among the surfaces ( $p>0.05)$.

Table 2. Mean \pm standard deviation for maximum and minimum strength and fatigue index on three different surfaces.

\begin{tabular}{lccc}
\hline & Cement & Grass & Sand \\
\hline MAXS (W) & $509.26 \pm 114.96$ & $504.99 \pm 114.15$ & $468.27^{\star} \pm 104.80$ \\
MINS (W) & $414.98 \pm 91.55$ & $410.77 \pm 100.27$ & $373.25^{\star} \pm 87.72$ \\
FI & $2.70 \pm 0.88$ & $2.66 \pm 0.65$ & $2.45 \pm 0.80$ \\
\hline
\end{tabular}

Note. * significant difference $(p<0.001)$ compared to cement and grass; MAXS $(W)$ - Maximum strength (Watts); MINS (W) - Minimum strength (Watts); FI - Fatigue index.

\section{DISCUSSION}

The present study aimed to analyze the anaerobic power and fatigue index using RAST on three different surfaces (cement, grass, and sand). The results showed lower minimum and maximum strength on the sand when compared to cement and grass, with no difference between the later surfaces, and with no difference regarding fatigue index in all surfaces.

Fatigue index has been used to describe the processes that calculate the reduction of anaerobic power performance, affecting the performance of athletes ${ }^{19}$. Thus, this study corroborates those from Araújo Junior et al. ${ }^{20}$, which analyze fatigue index through RAST with 13 soccer player and 13 futsal players, calculating their fatigue indexes and did not find any differences between both surfaces.

Fatigue index using RAST under different surfaces and types of shoes was also investigated by Kalva-Filho et al. ${ }^{9}$ The results were similar to those on these studies, with no difference in track or grass. However, the 
researchers did not study RAST results on the sand. It has been noted that RAST is widely used to evaluate fatigue index, however, only a few studies used several surfaces to evaluate its response.

On the other hand, the findings from Kalva-Filho et al. ${ }^{9}$ were different regarding maximum anaerobic power since it was demonstrated better maximum strength on track when compared to grass. Those differences may be related to several factors as physical conditioning, gender, weather conditions, shoes, among others.

Anaerobic power of RAST on grass and cement court was also investigated by Gonçalves et al. ${ }^{21}$ in 159 athletes from several sports, including volleyball, futsal, handball, basketball, and soccer using specific shoes for those disciplines. There was no difference for maximum strength on cement when compared to grass, in agreement with the results obtained by this study.

The difference in maximum streght on different surfaces may be explained by a higher energy cost on sand and grass, directly proportional to speed $^{21,22}$. Another factor may be the higher grip on hard surfaces when compared to grass and sand, thus, influencing performance increase on RAST $^{23-26}$. Otherwise, smaller strength on sand may be due to higher energy cost and physical effort inherent to this surface. In sand sprints, feet may slide on one of the steps phases, losing part of the surface reaction strength that would propel the individual forward ${ }^{15}$.

This may be the first study to investigate RAST performance on cement, grass, and sand, pointing that the type of surface is a key factor that must be considered to RAST application. There are some limitations on this study as the sprint barefoot on sand, fatigue from previous tries, and the fact of some subject not being familiar to sprint in some surfaces.

\section{CONCLUSION}

The RAST performance on sand is lower when compared to cement, and grass while the fatigue index was not influenced by the type of surface where the test is conducted.

\section{COMPLIANCE WITH ETHICAL STANDARDS}

\section{Funding}

This research did not receive any specific grant from funding agencies in the public, commercial, or not-for-profit sectors. This study was funded by the authors.

\section{Ethical approval}

Ethical approval was obtained from the local Human Research Ethics Committee: Centro Universitário Central Paulista (number: 1705382), and the protocol was written in accordance with the standards set by the Declaration of Helsinki. 


\section{Conflict of interest statement}

The authors have no conflict of interests to declare

\section{Author Contributions}

Conceived and designed the experiments: WRS, CJD, IAFS, PPP and WRS. Performed the experiments: WRS, IAFS and WRS. Analyzed data: WRS, IAFS, MMG, GAFC and WRS. Contributed with materials and analysis tools: WRS, WRS, CJD, IAFS and AFS. Wrote the paper: WRS, AFS, CJD, MMG, IAFS, GAFC and PPP.

\section{REFERENCES}

1. Barnes KR, Kilding AE. Strategies to improve running economy. Sports Med 2015;45(1):37-56.

2. Barbanti VJ. Treinamento esportivo: as capacidades motoras dos esportistas. Champaign: Manole; 2010.

3. Coelho DB, Morandi RF, Paixão RCd, Mendes TT, Borba DdA, Barros CLMd, et al. Limiar anaeróbico de 4, 0mM é capaz de estimar a máxima fase estável de lactato de jogadores de futebol em testes de campo. Rev Bras Cienc Mov 2015;23(2):32-39.

4. Veller C, Nowak MA, Davis CC. Extended flowering intervals of bamboos evolved by discrete multiplication. Ecology Letters 2015;18(7):653-9.

5. Glaister M, Lockey RA, Abraham CS, Staerck A, Goodwin JE, McInnes G. Creatine Supplementation and Multiple Sprint Running Performance. J Strength Cond Res 2006;20(2):5.

6. Cavazzotto TG, BRAZ AG, Ferreira SA, Queiroga MR. Efeito da aprendizagem no desempenho de repetidos testes de Wingate. Rev Bras Ciênc Esporte 2014;36(1):59-69.

7. Silva A, Marins J. Proposta de bateria de testes físicos para jovens jogadores de futebol e dados normativos. Rev Bras Futebol 2014;6(2):13-29.

8. Souza VAFA, de Oliveira Pires F, Lima-Silva AE, Bertuzzi R. Relação entre o desempenho no running based anaerobic sprint test (RAST) e a altura do salto vertical, salto horizontal e agilidade em futebolistas. Acta Bras Mov Hum 2012;2(1):34-45.

9. Kalva-Filho CA, Loures JP, Franco VH, Kaminagakura EI, Zagatto AM, Papoti M. Comparação da potência anaeróbia mensurada pelo teste de Rast em diferentes condições de calçado e superfícies. Rev Bras Med Esporte 2013;19(2):139-42.

10. Cetolin T, Foza V, Silva JF, Guglielmo LGA, Siqueira OD, Cardoso MFS, et al. Comparison of anaerobic power between tactical positions in soccer players: a retrospective study. Rev Bras Cineantropom Desempenho Hum 2013;15(4):507-16.

11. Dantas E. A prática da preparação física. Champaign: Roca; 2014.

12. Almeida B, Loureiro J. Perfil anaeróbio obtido pelo running anaerobic sprint test (rast) no período précompetitivo de atletas inscritos no campeonato paraense sub20 de 2013. Rev Bras Futebol 2014;6(2):39-46.

13. Kunduracioglu B, Guner R, Ulkar B, Erdogan A. Can heart rate values obtained from laboratory and field lactate tests be used interchangeably to prescribe exercise intensity for soccer players? Adv Ther 2007;24(4):890-902.

14. Brechue WF, Mayhew JL, Piper FC. Equipment and running surface alter sprint performance of college football players. J Strength Cond Res 2005;19(4):821-5.

15. Zamparo P, Perini R, Orizio C, Sacher M, Ferretti G. The energy cost of walking or running on sand. Eur J Appl Physiol Occup Physiol 1992;65(2):183-7.

16. Strydom NB, Bredell GAG, Benade AJS, Morrison JF, Viljoen JH, Graan CHV. The Metabolic Cost of Marching at 3 M.P.H. Over Firm and Sandy Surfaces. Int Z Angew Physiol Einschl Arbeitsphysiol 1966;23(2):166-171.

17. Zagatto AM, Beck WR, Gobatto CA. Validity of the running anaerobic sprint test for assessing anaerobic power and predicting short-distance performances. J Strength Cond Res 2009;23(6):1820-7. 
18. Keir DA, Thériault F, Serresse O. Evaluation of the running-based anaerobic sprint test as a measure of repeated sprint ability in collegiate-level soccer players. J Strength Cond Res 2013;27(6):1671-1678.

19. Oliver JL. Is a fatigue index a worthwhile measure of repeated sprint ability? J Sci Med Sport 2009;12(1):20-23.

20. Junior JHA, Marques RF, Costa HA, Marques KRM, de Almeida RB, de Oliveira Júnior MNS. Comparação do teste de Rast em jogadores de futebol e futsal de nível universitário. Rev Bras Prescr Fisiol Exerc 2012;6(34):367-371.

21. Gonçalves HR, de Arruda M, Valoto TA, Alves AAC, de Arruda Silva F, Fernandes F. Análise de informações associadas a testes de potência anaeróbia em atletas jovens de diferentes modalidades esportivas. Arq Ciênc Saúde Unipar 2007;11(2):115-121.

22. Strydom N, Bredell G, Benade A, Morrison J, Viljoen J, Van Graan C. The metabolic cost of marching at $3 \mathrm{mph}$ over firm and sandy surfaces. Int $\mathrm{Z}$ Angew Physiol1966;23(2):166-71.

23. Lejeune TM, Willems PA, Heglund NC. Mechanics and energetics of human locomotion on sand. J Exp Biol 1998;201(13):2071-80.

24. Haisman M, Goldman R. Effect of terrain on the energy cost of walking with back loads and handcart loads. J Appl Physiol 1974;36(5):545-8.

25. Soule RG, Goldman RF. Terrain coefficients for energy cost prediction. J Appl Physiol 1972;32(5):706-8.

26. Nummela AT, Heath KA, Paavolainen LM, Lambert MI, Gibson ASC, Rusko HK, et al. Fatigue during a 5-km Running Time Trial. Int J Sports Med 2008;29(9):738-745.

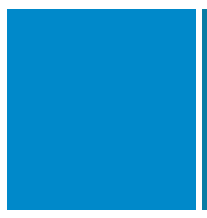

Corresponding author

Walmir Romário dos Santos

University of São Paulo, School of Physical Education and Sports of Ribeirão Preto.

Av. dos Bandeirantes, $n^{0}$ 3.900. Monte Alegre, Ribeirão Preto, São Paulo, Brazil.

ZIP Code: 14040-907.

Email:walmir@usp.br 